\title{
A Study on Exclusion and Inclusion of Dalits in Education
}

\author{
S. Kalaiselvan* and K. Maheswari ** \\ "Ph.D Scholar, Department of Social Work, Bharathidasan University College, Perambalur. Tamil Nadu, India. \\ ${ }^{* *}$ Head, Department of Social Work, Bharathidasan University College, Perambalur, Tamil Nadu, India.
}

\begin{abstract}
In India, few systematic studies have been undertaken to evaluate the effectiveness of financing of education in mitigating inequalities in educational opportunity. The study made by Chitnis (1972) presents some facts regarding the situation of scheduled caste students in higher education, in the country in general, and in Maharashtra in particular. In this study, the author has tried to find out the distribution of benefits of educational expenditure among scheduled caste people. By comparing the variables, percentage enrolment and percentage population of scheduled castes, the study tries to find out the quantum of beneficiaries of scheduled caste population.
\end{abstract}

Keywords: Social Exclusion, Inclusion, Education, Scheduled Caste.

\section{Introduction}

The development of any country mostly depends upon its growth of education in society. Progress of a society is possible only when its citizens are dynamic, resourceful, enterprising and responsible. Without such citizens, progress of country cannot be achieved in any field. Education herein helps in creating such type of citizens. It is the most important single factor in achieving rapid economic development and technological progress. According to Hiryakkanavar and Patil (2008) it is an established fact that education is an important catalyst of socio-economic transformation. In the advanced industrial societies of the world, education is provided by the states as a matter of right to all citizens. The development of primary education is treated as the foundation for literacy, which is considered as essential for development and more vital for emancipation of men and women. In the development of any country, primary education helps in creating base while higher education is important for providing the cutting edge. Higher educational institutions are contributing much to the national development by the way of providing specialized knowledge and skilled manpower. Therefore, higher education is considered to be an important instrument for the development of any country, particularly for a developing country like India (Ahmad, 2010). Chaudhari (2009) has stressed that overall illiteracy in the country around 70 per cent. It is perhaps not incorrect to point out that almost 70 per cent of people live in rural, tribal and slum areas of the country. The central and state governments are also slashing the services and securities for the working and deprived class to provide lower taxes, and higher subsidies for the rich. To promote a smart and vibrant cultural and educational life in deprived areas, huge financial funding is required. Bose and Velmurugan (2008) have pointed out that, education being the most potent instrument of creation, assimilation and transmission of knowledge, assumes a central role in the process very few educational researchers or theorists have attempted to cultural dimensions of globalization and the policies and practices of education. Mehendale (2010) has argued that the right of children of free and compulsory education Act of 2009 received presidential assent on 26 August 2009. As per the act, it is the duty of the appropriate government and local authority to ensure that children belonging to disadvantaged groups and weaker sections are not discriminated against and prevented from pursuing and completing elementary education. Private unaided schools and schools belonging to 'specified category' are required to admit at least 25 per cent of the total strength of children belonging to SC/ST categories from the neighborhood starting from class 1 or pre-school.

\section{Review of Literature}

According to Banerji (2000) universal primary education implies that every child lasts through the primary school stage and that every child learns of the poor. A comprehensive data-collection effort was made in 1994-95 to get a better grasp of the issues related to primary education faced by families and schools in the area. Iqbal (2003) is of the view that any reservations of quota by any external agency for non-minority students including SC and ST as such reservations cannot be claimed to promote educational standards or efficiency of the minority institutions. Dutta (2005) has stated that educational and occupational reservations have made lasting impact on India's political system. The dalits have not realized the importance of these courses and therefore remained outside the purview of vocational education. Kanmony (2006) has pointed out that the dalits have been facing various atrocities, which led them poor education in Tamil Nadu. In spite of various acts against socially deprived, even before British period, these groups have not been protected from their social and 
economic evils. Ajith Kumar and George (2009) have specifically mentioned that the facilities for higher and technical education are available to rural students at a reasonable distance. The literacy rates of SCs population, though lower than those of the general population in the state, are higher than the literacy rates of the tribal population in India. The government will seriously consider the own policies that relate to our own conditions and future. Even now the literacy rate of SCs has not reached 50 per cent (Devi 2009). Their formative years of education pick up necessary social skills and cultivate attitudes and value systems are necessary for a harmonious living. Ashappa and Sultana (2009) have observed that in case of rural environment, girls born in the backward families (particularly SC/ST), it is still more difficult to get education and employment. In higher education the performance of SC students both in enrollment and their performance are poor when couponed to the general population. Further the female ratio is very poor in the country on these aspects. Gurupandi and Amutharani (2010) have noticed that the higher education in India is made up of regular education and distance education. There are four type of regular education general, technical, medical and agriculture with each type divided into university level and research in science, technology status of deemed universities or autonomous institutions and provide higher education. Distance education is university based and it is limited to undergraduate, post-graduate degree and diploma courses in general and technical education. Higher education cannot solve all the society's problems; it can act as a resource. Gurupandi and Amutharani (2010) have focused the need for uniform education to the state of Tamil Nadu. The Uniform Education System explains the purpose of the scheme and it will provide the same type of education to all children in all schools without any discrimination to create equality among the people. The uniform quality education will reach all sections of the society and it will remove the discrimination between the rural students and the urban students.

\section{Scheduled Castes in India}

Many other nations are characterized by social inequality but nowhere else in the world inequality been as extremely constructed by the institution of caste as in the India. It is a known fact that education is closely linked to development. Historical evidences in this regard indicate that Dalit community has been excluded from the whole process of education since centuries. After the formation of the Constitution of India, education was supposed to be made "accessible to all". Caste has long existed in India, but in the modern period it has been severely criticized by both Indian and foreign observers. Although some educated Indians tell non- Indians that caste has been abolished or that no one pays attention to caste anymore; such statements do not reflect reality. Caste has undergone significant change since independence, but it still involves hundreds of millions of people in its preamble, India's constitution forbids negative public discrimination on the basis of caste. However, caste ranking and caste-based interaction have occurred for centuries and will continue to do so well into the foreseeable future, more in the countryside than in urban settings and more in the realms of kinship and marriage than in less personal interactions (Chauhan 2008). The SC Population numbering 138 million (1991) in India accounts for 16.48per cent of the total population of the country now increased to 166 million (2001) accounts for 16.63 per cent of total population of the country which shows that there has been increase a share of SC population in the last decade. The states with higher concentration of SC population are Uttar Pradesh, Bihar, West Bengal, Andhra Pradesh and Tamil Nadu, these five states together account for around 58 per cent of the total SC Population of the country (Chauhan 2008).

\section{Scheduled Castes in Post-Independence Period}

After independence, the Scheduled Castes (SCs) and Scheduled Tribes (STs) received special attention through the Constitution of India with special provisions in education, employment and political representation. Article 46, for instance, declares: "The State shall promote with special care the educational and economic interests of the weaker sections of the people and in particular of the Scheduled Castes and Scheduled Tribes, and shall protect them from social injustice and all forms of exploitation." Untouchability was declared abolished under Article 17. Consequently, avenues had been opened to these people to enter into modern and secular sectors of development which are based on rationality as against the tradition and religion. As a result, the philosophy of equality and equal opportunity was cherished during the period. However, as revealed by many studies, restricted access to education has been a matter of great social concern ever since the notion of equality of educational opportunity gained recognition as a basic human right. Studies have established that access to and performance in education continues strongly to be a function of social background-caste, class, race and sex are the major factors that operate. The UNICEF and UNESCO (2014) have reported that Dalit girls have the highest primary school exclusion rate in India. The report also indicates that half of the pre-school aged dalit children are not attending school and the contributing factors to higher rates of exclusion are deep-rooted social inequalities and poverty among dalits (Scheduled Castes). The report also stated that, humiliation, harassment and abuse by upper caste teachers towards children from scheduled castes de-motivated the children to stay in school. Child labour was identified as another key hindrance to children attending school. According 
to the ILO, India has the highest number of working children in the world. Most of these children belong to the poorest, most marginalized communities, including Scheduled Castes and Scheduled Tribes."

\section{Literacy Rates of SC and ST population}

\begin{tabular}{|l|l|l|l|}
\hline \multicolumn{2}{|l|}{} & $\mathbf{2 0 0 1}$ & $\mathbf{2 0 1 1}$ \\
\hline 11 & Male Literacy rate & 75.3 & 84.14 \\
\hline 12 & Female Literacy rate & 53.7 & 65.46 \\
\hline 13 & Gender Gap in Literacy & 21.6 & 16.68 \\
\hline \multicolumn{2}{|l|}{} & $\mathbf{1 9 9 1}$ & $\mathbf{2 0 0 1}$ \\
\hline 14 & Literacy rates for SC & 37.41 & 54.69 \\
\hline 15 & Literacy rates for SC (Male) & 49.91 & 66.64 \\
\hline 16 & Literacy rates for SC (Female) & 23.67 & 41.9 \\
\hline 17 & Literacy rates for ST & 29.6 & 47.1 \\
\hline 18 & Literacy rates for ST (Male) & 40.65 & 59.17 \\
\hline 19 & Literacy rates for ST (Female) & 18.19 & 47.1 \\
\hline
\end{tabular}

Source: Human Development Report, 2000 and 2011.

\section{Conclusion}

Scheduled Castes have been considered the weakest constituents of the Indian social structure followed by the Scheduled Tribes. However crimes committed against women have increased over time. Human development indicators are much lower for SC and ST. Multidimensional poverty among SC and ST is alarmingly high with over $2 / 3 \mathrm{rd}$ of SC and over $3 / 4$ th of ST population deemed multi-dimensionally poor. Indian supporters believe that only a private schooling system can save education from its awfully degraded quality and make it available to the darkest corners of illiterate households. The SC children, while consisting nearly 45 per cent of the total enrolment in the general public school, and only about 18 per cent of the total enrolment in private schools. A large variation in the cost of schooling was found among different social groups like Muslim, Hindu and others. The average cost of schooling among the SCs is higher than that of ST and less than that of general and minorities (Kumar Rana et.al, 2005). Primary role of various governmental development schemes and various public services in villages like Anganwadi, public health centers etc and school is development of general public with respect to education, health and nutrition. The government monitoring and reporting system must work promptly to make sure that anganwadi people work more effectively and efficiently without discrimination. There is a need to create an environment to join Dalit community to public services and to eliminate the reasons for their social exclusion. Continuous and intensive efforts are required to eliminate this problem from the society.

\section{References}

[1]. Banerji, R. (1997) Why Don't Children Complete Primary School?: A Case Study of a Low-Income Neighbourhood in Delhi, Economic and Political Weekly, Vol. 32, No. 32, pp. 2053-2063.

[2]. Banerji, R. (2000) Poverty and Primary Schooling: Field Studies from Mumbai and Delhi, Economic and Political Weekly, Vol. XXXV No. 10, March 4, pp. 795-802.

[3]. Census 2001 and 2011, Provisional Population. Totals Paper 1 of 2011 India series1, Registrar General of India.

[4]. Crime in India 2000 and 2010, Ministry of Home Affairs, GOI.

[5]. George, K K and Kumar Ajith, N. (2009), “Kerala’s Education System: From Inclusion to Exclu-sion?”, Economic andPolitical Weekly, October 10, VOL. XLIV, No .41.

[6]. George, K.K. (2011), Higher Education in Kerala: How Inclusive is it to Scheduled Castes and Scheduled Tribes?, Working Paper , Centre for Socio-economic \& Environmental Studies, Kochi.

[7]. Gendering Human Development Indices: Recasting GDI and GEM for India. 2009, Ministry of Women and Child Development, and UNDP.

[8]. Human Development Report 2011 and Human Development Report 2000, UNDP.

[9]. Millennium Development Goals: India Country Report 2011, CSO.

[10].Planning Commission for 2001 and National Literacy Mission for 1991

[11].Special Bulletin on Maternal Mortality in India 2007-09, SRS, June 2011. 